\title{
EFFECT OF DIFFERENT FITNESS PROGRAMS ON THE MORPHOLOGICAL PARAMETERS OF WOMEN AGED 30-40 YEARS
}

\author{
E.A. Perevalina ${ }^{1}$, perevalinaelena@yandex.ru, ORCID: 0000-0001-8288-9357, \\ M.M. Shestakov', shmm@mail.ru, ORCID: 0000-0001-6051-4861, \\ S.A. Laggao², laggao@yandex.ru, ORCID: 0000-0002-0623-0726 \\ ${ }^{1}$ Kuban State University of Physical Culture, Sport and Tourism, Krasnodar, Russian Federation, \\ ${ }^{2}$ Njala University, Freetown, Sierra Leone
}

\begin{abstract}
Aim. The article deals with establishing the features of changes in the morphological parameters of women aged 30-40 years involved in different fitness programs at the basic stage. Materials and methods. 85 women aged 30-40 years participated in different fitness programs during 9 weeks: 17 - gym, 19 - traditional aerobics, 17 - strength aerobics, 17 - functional training, 15 - fitness-yoga. 60-minute fitness lessons were conducted 3 times per week. We measured the following parameters: height, weight, body circumference, skin-fat fold volume, the absolute and relative values of the muscle and fat tissues. Results. In women, body mass reduces under the effect of gym training, traditional aerobics, and functional training. The reduction of body circumference measurements occurs under the effect of gym training, traditional aerobics, strength aerobics, and functional training. Muscle mass increases as a result of gym training and decreases after traditional aerobics. The absolute and relative mass of the fat tissue reduces under the effect of gym training, traditional aerobics, and functional training. Conclusion. Different fitness programs influence differently morphological status in women aged 30-40 years.
\end{abstract}

Keywords: women, average age, fitness programs, morphological parameters.

Introduction. The age period of 30-40 years is especially important for women as it is critical for reproductive health, physiological activity, and the functional status of the body in general $[5,7]$. Women of this age actively perform social, family, educational, organizational, and management roles [6]. In modern society, the lifestyle of middle-aged women is characterized by insufficient physical activity with low temp and movement volume [8]. Sedentary lifestyle results in excess weight and obesity, leading to the reduction of overall working efficiency and endurance, as well as to the cardiovascular, musculoskeletal, and metabolic disorders [12]. Such disorders require regular physical activity [14].

Modern fitness clubs offer a wide range of fitness programs to satisfy women's needs in physical activity $[2,3,9,11,13,15]$. However, focused fitness programs cannot provide an overall effect on the morphological parameters of middle-aged women and satisfy their needs in weight reduction and body correction. This leads to the necessity of their targeted integration $[4,10]$.

Solving this problem requires objective information about the effect of different fitness programs on the morphological status of people.

Aim. The article deals with establishing the features of changes in the morphological parame- ters of women aged 30-40 years involved in different fitness programs at the basic stage.

Materials and methods. 85 middle-aged women with excess weight and I or II grade obesity participated in the study. All women were divided into 5 groups depending on their fitness program: 17 - gym, 19 - traditional aerobics, $17-$ strength aerobics, 17 - functional training, 15 fitness-yoga. 60-minute fitness lessons were conducted three times per week. The exercise experience of women was no more than two months. Anthropometric data were obtained according to a standard protocol [1]. At the beginning of the training course, we measured height, weight, body circumference, skin-fat fold volume, the absolute and relative values of the muscle and fat tissues. The second measurement was conducted in 2 months.

Results. The study allowed us to reveal a different effect of 9-week fitness programs on the morphological parameters of middle-aged women (Table).

In particular, in women attending gym, we registered the following changes in the parameters studied:

- body mass reduced from $68.0 \pm 1.16$ to $64.5 \pm 1.12 \mathrm{~kg}(\mathrm{t}=2.17 ; \mathrm{p}<0.05)$;

- body circumference decreased both in 
Table Changes in the morphological status of middle-aged women under the effect of different fitness programs

\begin{tabular}{|c|c|c|c|c|c|c|c|}
\hline \multirow{3}{*}{$\begin{array}{l}\text { Fitness } \\
\text { programs }\end{array}$} & \multicolumn{7}{|c|}{ Morphological parameters } \\
\hline & \multirow[b]{2}{*}{$\begin{array}{l}\text { Body } \\
\text { mass }\end{array}$} & \multirow{2}{*}{$\begin{array}{l}\text { Body } \\
\text { circum- } \\
\text { ference }\end{array}$} & \multirow{2}{*}{$\begin{array}{l}\text { Skin-fat } \\
\text { fold } \\
\text { volume }\end{array}$} & \multicolumn{2}{|c|}{ Muscle mass } & \multicolumn{2}{|c|}{ Fat mass } \\
\hline & & & & Absolute & $\begin{array}{c}\% \text { of body } \\
\text { weight }\end{array}$ & Absolute & $\begin{array}{c}\% \text { of body } \\
\text { weight }\end{array}$ \\
\hline $\begin{array}{l}\text { Gym } \\
(\mathrm{n}=17)\end{array}$ & $\nabla$ & $\nabla$ & $\nabla$ & $\Delta$ & $\Delta$ & $\nabla$ & $\nabla$ \\
\hline $\begin{array}{l}\text { Traditional } \\
\text { aerobics } \\
(\mathrm{n}=19)\end{array}$ & 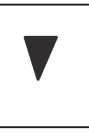 & $\nabla$ & $\nabla$ & 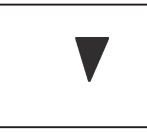 & & $\nabla$ & $\nabla$ \\
\hline $\begin{array}{l}\text { Aerobics } \\
\text { (strength) } \\
(\mathrm{n}=17)\end{array}$ & & & & & & & $\nabla$ \\
\hline $\begin{array}{l}\text { Functional } \\
\text { training } \\
(\mathrm{n}=17)\end{array}$ & $\nabla$ & 7 & 7 & & & $\nabla$ & $\nabla$ \\
\hline $\begin{array}{l}\text { Yoga } \\
(\mathrm{n}=15)\end{array}$ & & & & & & & \\
\hline
\end{tabular}

Note: $\boldsymbol{\Lambda}_{\text {-increase; }} \boldsymbol{\nabla}$-decrease; - unchanged.

general and in certain areas: in general (from $149.0 \pm 0.85$ to $145.8 \pm 0.86 \mathrm{~cm}, \mathrm{t}=2.66$, $\mathrm{p}<0.01$ ); pelvic circumference (from $99.9 \pm 0.58$ to $97.6 \pm 0.58 \mathrm{~cm}, \mathrm{t}=2.80, \mathrm{p}<0.01)$; maximal lower arm circumference (from $24.4 \pm 0.10$ to $23.9 \pm 0.09 \mathrm{~cm}, \mathrm{t}=3.55, \mathrm{p}<0.001)$; calf circumference (from $36.4 \pm 0.26$ to $35.6 \pm 0.27 \mathrm{~cm}$, $\mathrm{t}=2.12, \mathrm{p}<0.05$ ); hip circumference (from $58.6 \pm$ \pm 0.39 to $57.4 \pm 0.40 \mathrm{~cm}, \mathrm{t}=2.15, \mathrm{p}<0.05)$; shoulder circumference in the relaxed state (from $29.5 \pm 0.22$ to $28.8 \pm 0.21 \mathrm{~cm}, \mathrm{t}=2.27, \mathrm{p}<0.05)$; waist circumference (from $77.5 \pm 0.73$ to $74.1 \pm$ $\pm 0.64 \mathrm{~cm}, \mathrm{t}=3.51, \mathrm{p}<0.001)$;

- absolute muscle mass increased from $26.43 \pm 0.33$ to $27.45 \pm 0.35 \mathrm{~kg}(\mathrm{t}=2.13$; $\mathrm{p}<0.05$ ), while the percentage of muscle mass in body composition increased from $39 \%$ to $43 \%$ $(\mathrm{t}=7.38 ; \mathrm{p}<0.001)$

- absolute fat mass decreased from $21.03 \pm$ \pm 0.48 to $16.07 \pm 0.37 \mathrm{~kg}(\mathrm{t}=8.23 ; \mathrm{p}<0.001)$, while the percentage of fat mass in body composition decreased from $30.7 \pm 0.48$ to $24.7 \pm 0.36 \%$ $(\mathrm{t}=10.03 ; \mathrm{p}<0.001)$;

- skin-fat fold volume decreased both in general and in certain areas: in general $(76.9 \pm$ \pm 1.23 to $59.1 \pm 1.04 \mathrm{~mm}, \mathrm{t}=11.08 ; \mathrm{p}<0.001)$; the frontal part of the shoulder (from $10.7 \pm 0.19$ to $7.62 \pm 0.20 \mathrm{~mm}, \mathrm{t}=11.26, \mathrm{p}<0.001)$; the back part of the shoulder (from 18.26 \pm 0.45 to $14.26 \pm 0.31 \mathrm{~mm}, \mathrm{t}=7.26, \mathrm{p}<0.001)$; lower arm (from $11.24 \pm 0.19$ to $7.76 \pm 0.17 \mathrm{~mm}, \mathrm{t}=13.70$, $\mathrm{p}<0.001$ ); abdomen (from $16.68 \pm 0.36$ to $14.12 \pm$ $\pm 0.30 \mathrm{~mm}, \mathrm{t}=5.45, \mathrm{p}<0.001)$; under the shoul- der blade (from $17.41 \pm 0.63$ to $14.35 \pm 0.49 \mathrm{~mm}$, $\mathrm{t}=3.83, \mathrm{p}<0.001)$; the frontal part of the hip (from $29.53 \pm 0.64$ to $24.00 \pm 0.57 \mathrm{~mm}, \mathrm{t}=6.44$, $\mathrm{p}<0.001$ ); calf (from $21.71 \pm 0.42$ to $16.41 \pm$ $\pm 0.34 \mathrm{~mm}, \mathrm{t}=9.83, \mathrm{p}<0.001)$.

In women attending traditional aerobics, we registered the following features of changes in the parameters of the morphological status:

- body mass reduced from $72.18 \pm 2.21$ to $66.21 \pm 1.95 \mathrm{~kg}, \mathrm{t}=2.21, \mathrm{p}<0.05$

- body circumference decreased both in general and in certain areas: in general (from $155.39 \pm$ \pm 1.94 to $144.82 \pm 1.98 \mathrm{~cm}, \mathrm{t}=3.81, \mathrm{p}<0.001)$; pelvic circumference (from $103.53 \pm 1.42$ to $98.34 \pm 1.31 \mathrm{~cm}, \mathrm{t}=2.68, \mathrm{p}<0.001)$; hip circumference (from $61.53 \pm 0.85$ to $57.6 \pm 0.90 \mathrm{~cm}$, $\mathrm{t}=3.18, \mathrm{p}<0.05)$; shoulder circumference in the relaxed state (from $31.18 \pm 0.70$ to $28.58 \pm 0.62 \mathrm{~cm}$, $\mathrm{t}=2.79, \mathrm{p}<0.05)$; maximal lower arm circumference (from $25.53 \pm 0.26$ to $23.95 \pm 0.25 \mathrm{~cm}$, $\mathrm{t}=4.42, \mathrm{p}<0.05$ ); calf circumference (from $37.16 \pm 0.55$ to $34.71 \pm 0.59 \mathrm{~cm}, \quad \mathrm{t}=3.03$, $\mathrm{p}<0.05$ ); waist circumference (from $79.79 \pm 1.66$ to $74.47 \pm 1.40 \mathrm{~cm}, \mathrm{t}=2.44, \mathrm{p}<0.01$ );

- absolute muscle mass decreased from $28.80 \pm 0.79$ to $25.89 \pm 0.74 \mathrm{~kg}(\mathrm{t}=2.70, \mathrm{p}<0.05)$ against the unchanged muscle mass in body weight composition;

- absolute fat mass decreased from $24.12 \pm$ \pm 1.19 to $18.55 \pm 0.98 \mathrm{~kg}(\mathrm{t}=3.61 ; \mathrm{p}<0.001)$, while the percentage of fat mass in body weight composition decreased from $38.2 \pm 1.00$ to $27.8 \pm$ $\pm 0.96 \%(\mathrm{t}=3.89, \mathrm{p}<0.001)$; 


\section{Физиология}

- skin-fat fold volume decreased both in general and in certain areas: in general (from $82.6 \pm$ \pm 3.32 to $70.4 \pm 3.22 \mathrm{~mm}, \mathrm{t}=2.65, \mathrm{p}<0.05)$; the frontal part of the shoulder (from $10.95 \pm 0.65$ to $9.16 \pm 0.51 \mathrm{~mm}, \mathrm{t}=2.17, \mathrm{p}<0.05)$; the back part of the shoulder (from $21.26 \pm 1.30$ to $17.53 \pm$ $\pm 1.24 \mathrm{~mm}, \mathrm{t}=2.09, \mathrm{p}<0.05$ ); lower arm (from $11.16 \pm 2.29$ to $9.53 \pm 2.37 \mathrm{~mm}, \mathrm{t}=2.16, \mathrm{p}<0.05)$; abdomen (from $20.53 \pm 4.06$ to $15.05 \pm 2.97 \mathrm{~mm}$, $\mathrm{t}=4.74, \mathrm{p}<0.001)$; under the shoulder blade (from $20.79 \pm 6.58$ to $14.05 \pm 3.91 \mathrm{~mm}, \mathrm{t}=3.84$, $\mathrm{p}<0.001$ ); the frontal part of the hip (from $35.16 \pm$ \pm 1.43 to $30.50 \pm 1.44 \mathrm{~mm}, \mathrm{t}=2.29, \mathrm{p}<0.05)$; calf (from $20.24 \pm 1.04$ to $17.05 \pm 1.09 \mathrm{~mm}$, $\mathrm{t}=2.12, \mathrm{p}<0.05)$

In women involved in strength aerobics, we registered the following features:

- body mass did not change statistically significant $(\mathrm{t}=1.97, \mathrm{p}>0.05)$;

- body circumference decreased both in general and in certain areas: in general (from $161.5 \pm$ \pm 2.37 to $152.3 \pm 2.37 \mathrm{~cm}, \mathrm{t}=2.73, \mathrm{p}<0.05)$; pelvic circumference (from $105.5 \pm 1.56$ to $100.8 \pm$ $\pm 1.58 \mathrm{~cm}, \mathrm{t}=2.13, \mathrm{p}<0.05) ;$ hip circumference (from $61.6 \pm 1.1$ to $58.4 \pm 1.03 \mathrm{~cm}, \mathrm{t}=2.14$, $\mathrm{p}<0.05$ ); shoulder circumference in the relaxed state (from $33.4 \pm 0.79$ to $31.1 \pm 0.72 \mathrm{~cm}, \mathrm{t}=2.21$, $\mathrm{p}<0.05$ ); maximal lower arm circumference (from $26.9 \pm 0.37$ to $25.7 \pm 0.37 \mathrm{~cm}, \mathrm{t}=2.19$, $\mathrm{p}<0.05$ ); calf circumference (from $39.6 \pm 0.8$ to $37.1 \pm 0.8 \mathrm{~cm}, \mathrm{t}=2.18, \mathrm{p}<0.05)$; waist circumference (from $81.4 \pm 1.88$ to $75.9 \pm 1.76 \mathrm{~cm}$, $\mathrm{t}=2.12, \mathrm{p}<0.05)$

- there were no statistically significant changes in absolute muscle mass and the percentage of muscle mass in body weight composition $(\mathrm{t}=0.03$, $\mathrm{p}>0.05$ );

- absolute fat mass decreased from $28.65 \pm$ \pm 2.03 to $22.10 \pm 1.66 \mathrm{~kg}(\mathrm{t}=2.50, \mathrm{p}<0.05)$, while the percentage of fat mass in body weight composition decreased from $39 \pm 2.51 \%$ to $32 \pm$ $\pm 2.4 \%(\mathrm{t}=2.14, \mathrm{p}<0.05)$;

- skin-fat fold volume decreased both in general and in certain areas: in general (from $92.7 \pm$ \pm 4.72 to $76.7 \pm 4.66 \mathrm{~mm}, \mathrm{t}=2.41, \mathrm{p}<0.05$ ); the frontal part of the shoulder (from $15.3 \pm 0.85$ to $12.7 \pm 0.78 \mathrm{~mm}, \mathrm{t}=2.22, \mathrm{p}<0.05)$; the back part of the shoulder (from $23.9 \pm 1.83$ to $18.8 \pm$ $\pm 1.63 \mathrm{~mm}, \mathrm{t}=2.11, \mathrm{p}<0.05$ ); lower arm (from $12.8 \pm 0.60$ to $10.9 \pm 0.60 \mathrm{~mm}, \mathrm{t}=2.25, \mathrm{p}<0.05)$; the frontal part of the hip (from $36.8 \pm 1.92$ to $30.8 \pm 1.90 \mathrm{~mm}, \mathrm{t}=2.22, \mathrm{p}<0.05$ ); calf (from $23.5 \pm 1.33$ to $19.3 \pm 1.38 \mathrm{~mm}, \mathrm{t}=2.20, \mathrm{p}<0.05)$. There were no statistically significant changes in the skin-fat fold volume of the abdomen and under the shoulder blade.

In women involved in functional training, we registered the following features:

- body mass reduced from $70.71 \pm 1.52$ to $66.06 \pm 1.59 \mathrm{~kg}(\mathrm{t}=2.12 ; \mathrm{p}<0.05) ;$

- body circumference decreased both in general and in certain areas: in general (from $156 \pm$ \pm 1.78 to $149 \pm 1.74 \mathrm{~cm}, \mathrm{t}=2.80, \mathrm{p}<0.05)$; pelvic circumference (from $104 \pm 1.53$ to $99.1 \pm 1.35 \mathrm{~cm}$, $\mathrm{t}=2.39, \mathrm{p}<0.05$ ); hip circumference (from $62.1 \pm$ \pm 0.83 to $59.5 \pm 0.75 \mathrm{~cm}, \mathrm{t}=2.3, \mathrm{p}<0.05)$; shoulder circumference in the relaxed state (from $31.2 \pm$ \pm 0.67 to $29.1 \pm 0.71 \mathrm{~cm}, \mathrm{t}=2.12, \mathrm{p}<0.05)$; maximal lower arm circumference (from $25.3 \pm$ \pm 0.32 to $24.2 \pm 0.32 \mathrm{~cm}, \mathrm{t}=2.35, \mathrm{p}<0.05$ ); calf circumference (from $37.2 \pm 0.41$ to $35.9 \pm 0.4 \mathrm{~cm}$, $\mathrm{t}=2.19, \mathrm{p}<0.05$ ); waist circumference (from $81 \pm$ \pm 1.52 to $75.9 \pm 2.65 \mathrm{~cm}, \mathrm{t}=2.65, \mathrm{p}<0.05$ );

- there were no statistically significant changes in absolute muscle mass and the percentage of muscle mass in body weight composition $(\mathrm{t}=1.36$; $\mathrm{p}>0.05$ );

- absolute fat mass decreased from $25.5 \pm$ \pm 1.14 to $20.1 \pm 0.94 \mathrm{~kg}(\mathrm{t}=3.68, \mathrm{p}<0.001)$, while the percentage of fat mass in body weight composition decreased from $36.0 \pm 1.31$ to $30.4 \pm$ $\pm 1.37 \%(\mathrm{t}=2.94, \mathrm{p}<0.01)$

- skin-fat fold volume decreased both in general and in certain areas: in general (from $85.2 \pm$ \pm 3.50 to $70.4 \pm 3.38 \mathrm{~mm}, \mathrm{t}=3.05, \mathrm{p}<0.001$ ); the frontal part of the shoulder (from $11.3 \pm 0.71$ to $9.0 \pm 0.54 \mathrm{~mm}, \mathrm{t}=2.53, \mathrm{p}<0.05)$; the back part of the shoulder (from $22.4 \pm 1.20$ to $18.1 \pm$ $\pm 1.16 \mathrm{~mm}, \mathrm{t}=2.58, \mathrm{p}<0.05$ ); lower arm (from $11.4 \pm 0.62$ to $9.1 \pm 0.44 \mathrm{~mm}, \mathrm{t}=2.94, \mathrm{p}<0.01)$; abdomen (from $19.8 \pm 0.7$ to $15.6 \pm 0.6 \mathrm{~mm}$, $\mathrm{t}=4.62, \mathrm{p}<0.001$ ); under the shoulder blade (from $22.2 \pm 1.38$ to $18.3 \pm 1.18 \mathrm{~mm}, \mathrm{t}=2.17, \mathrm{p}<0.05)$; the frontal part of the hip (from $35.3 \pm 1.57$ to $29.7 \pm 1.55 \mathrm{~mm}, \mathrm{t}=2.55, \mathrm{p}<0.05$ ); calf (from $21.71 \pm 1.02$ to $18 \pm 1.17 \mathrm{~mm}, \mathrm{t}=2.38, \mathrm{p}<0.05$ ).

The analysis of the dynamics of the morphological status in women practicing fitness yoga revealed that such a training course did not influence their morphological parameters significantly.

Conclusion. The results of the study allowed us to conclude the following:

1. Body mass in middle-aged women decreases significantly as a result of gym exercises, traditional aerobics, and functional training.

2. Body circumference values in middleaged women decrease significantly under the ef- 
fect of gym exercises, traditional aerobics, strength aerobics, and functional training.

3. Skin-fat fold volume decreases significantly as a result of gym exercises, traditional aerobics, and functional training, while strength aerobics affects only specific problem areas.

4. Muscle mass both in absolute and relative values increases significantly under the effect of gym exercises, while traditional aerobics contributes to the decrease of muscle mass in the absolute values.

5. Fat mass both in absolute and relative values decreases significantly under the effect of gym exercises, traditional aerobics, strength aerobics, and functional training.

6. Solving effectively the important tasks of weight reduction, body correction, and changing the absolute values and percentage of the muscle and fat mass in body weight composition is only possible by combining different fitness programs.

\section{References}

1. Aleksanyants G.D., Abushkevich V.V., Tlekhas D.B., Filenko A.M., Anan'yev I.N., Grichanova T.G. Sportivnaya morfologiya: uchebno-metodicheskoye posobiye [Sport Morphology], 2nd ed. Krasnodar, KGUFKST Publ., 2007. $86 \mathrm{p}$.

2. Chernenko O.I., Gureyeva A.M. [The Influence of Different Types of Recreational Aerobics on the Level of Physical Fitness of Girls 18-20 Years Old]. Pedagogika, psikhologiya i medikobiologicheskiye problemy fizicheskoy kul'tury $i$ sporta [Pedagogy, Psychology, and Medical and Biological Problems of Physical Culture and Sport], 2010, no. 3, pp. 145-148. (in Russ.)

3. Enchenko I.V. [Analysis of the Attractiveness of Services in the Sphere of Physical Culture and Sports Among the Population]. Fizicheskaya kul'tura, sport - nauka i praktika [Physical Culture, Sport - Science and Practice], 2013, no. 2, pp. 33-38. (in Russ.)

4. Fedorova O.N. [Influence of the Pilates and Aqua Aerobics Health Complex on the components of the health of middle-aged women]. Adaptivnaya fizicheskaya kul'tura [Adaptive Physical Culture], 2011, no. 4 (48), pp. 26-28. (in Russ.)

5. Furman Y.M., Salnikova S.V. Improvement of Aerobic Energy Supply Processes in 37-49 Years Old Women by Means of Complex AquaFitness Trainings' and Methodic of Endogenous Hypoxic Breathing's Application. Pedagogics,
Psychology, Medical-Biological Problems of Physical Training and Sport, 2015, vol. 7, pp. 59-69. (in Ukr.) DOI: 10.15561/18189172. 2015.0708

6. Kadykova N.K., Fridel' L.E., Shorokhova M.A. [Fitness Workouts at Different Periods in the Life of Women]. Sborniki konferentsii NITS sotsiosfera [Collections of the SIC Sociosphere Conference], 2016, no. 56, pp. 538-543. (in Russ.)

7. Kunitsa Yu.B. [Features of Conducting Fitness Classes with Middle-Aged Women]. Nauka-2020 [Science-2020], 2016, no. 3 (9), pp. 133-138. (in Russ.)

8. Lanskaya O.V., Sazonova L.A., Gerasimova T.G. [Aqua Aerobics as a Means of Rehabilitation for Women 30-40 Years Old with Obesity Grade I-II]. Nauchnyy vestnik [Scientific Herald], 2017, no. 2(12), pp. 79-90. (in Russ.)

9. Martinova N.P. Determination of HEE Students' Motives and Interests to Physical Education Classes. Scientific and Pedagogical Problems of Physical Culture, 2015, vol. 3 (57, 15), pp. 218-222. (in Ukr.)

10. Martinova N.P. New Kinds of Aerobics as Mean of HEE Girl Students' Motor Skills' Training. Slobozhansky Scientific Sports Journal, 2014, vol. 1 (39), pp. 62-65. (in Ukr.)

11. Martyniuk O.V. Justification for Experimental Methods for Circuit Training Aerobics Classes First Mature Age Women. Pedagogics, Psychology, Medical-Biological Problems of Physical Training and Sports, 2014, vol. 11, pp. 30-37. (in Ukr.) DOI: 10.15561/18189172.2014.1106

12. Safronova D.V., Polyakova A.Yu. [The Importance of Behavioral Motivation as a Criterion for Customer Segmentation when Developing Programs for Personalizing Fitness Services]. Zhurnal U. Ekonomika. Upravleniye. Finansy [Journal U. Ekonomika. Control. Finance], 2018, no. 1 (11), pp. 70-76. (in Russ.)

13. Safronova N.S., Ikonnikova E.V., Fomenko A.V. et al. [Improving Training Effects of Interval Aerobic Training in Women of Mature Age]. Nauka, fitnes, reakriatsiya-2015 [Science, Fitness, Reactivity-2015], 2015, no. S, pp. 147-152. (in Russ.)

14. Todosyuk S.V., Gorsha O.V. [The Level of Health and the Pace of Aging in Women Involved in Fitness]. Aktual'nyye problemy transportnoy meditsiny [Actual Problems of Transport Medicine], 2014, no. 2-2 (36), pp. 80-83. (in Russ.)

15. Voronkov A.V., Nikulin I.N., Abuyezi- 
dov Kh.Kh. et al. [Use of Aerobic Exercises in the Framework of Strength Training]. Nauchnyy zhurnal DISKURS [DISCOURSE Scientific Journal], 2018, no. 11 (25), pp. 19-24. (in Russ.)

Received 5 May 2019

удк 796.4

DOI: $10.14529 / h s m 19 s 102$

\title{
ОСОБЕННОСТИ ВЛИЯНИЯ РАЗНЫХ ПРОГРАММ ФИТНЕСА НА МОРФОЛОГИЧЕСКИЕ ПОКАЗАТЕЛИ ЖЕНЩИН 30-40 ЛЕТ
}

\author{
Е.А. Перевалина ${ }^{1}$, М.М. Шестаков ${ }^{1}$, С.А. Лаггао ${ }^{2}$ \\ ${ }^{1}$ Кубанский государственный университет физической культуры, спорта и туризма, \\ г. Краснодар, Россия, \\ ${ }^{2}$ Университет Ньялы, г. Фритаун, Сьерра-Леоне
}

\begin{abstract}
Цель исследования. Определить особенности изменения морфологических показателей женщин 30-40 лет под воздействием тренировочных нагрузок разных программ фитнеса на базовом этапе занятий. Материалы и методы. Разные программы фитнеса девять недель реализовали 85 женщин 30-40 лет: 17 занимались в тренажерном зале, 19 - классической аэробикой, 17 - силовой аэробикой, 17 - функциональным тренингом, 15 - фитнесйогой. Занятия проводились 3 раза в неделю по 60 минут. Контролировались: рост, вес, обхватные размеры звеньев тела, толщина кожно-жировых складок, рассчитывались абсолютные и относительные показатели мышечной и жировой ткани. Результаты. Масса тела у женщин снижается под воздействием занятий в тренажерном зале, классической аэробикой и функциональной тренировкой. Уменьшение обхватных размеров звеньев тела происходит под воздействием занятий в тренажерном зале, классической аэробикой, силовой аэробикой, функциональной тренировкой. Толщина кожно-жировых складок уменьшается под воздействием занятий в тренажерном зале, классической аэробикой, функциональной тренировкой. Увеличению мышечной массы способствуют занятия в тренажерном зале, а уменьшению - классической аэробикой. Абсолютная и относительная масса жировой ткани уменышается при занятиях в тренажерном зале, классической аэробикой, функциональной тренировкой. Заключение. Тренировочные нагрузки разных программ фитнеса обладают специфическими особенностями воздействия на показатели морфологического статуса женщин 30-40 лет.
\end{abstract}

Ключевые слова: женщины, средний возраст, программы фитнеса, морфологические показатели.

\section{Лuтература}

1. Спортивная морфология: учеб.-метод. пособие / Г.Д. Алексаняни, В.В. Абушкевич, Д.Б. Тлехас и др. - 2-е изд., стер. - Краснодар: КГУФКСТ, 2007. - 86 с.

2. Черненко, О.И. Влияние занятий разными видами оздоровительной аэробики на уровень физической подготовленности девушек 18-20 лет / О.И. Черненко, А.М. Гуреева // Педагогика, психология и медико-биологические проблемы физической культуры и спорта. - 2010. - № 3. C. $145-148$.

3. Енченко, И.В. Анализ привлекательности услуг сферы физической культуры и спорта среди населения / И.В. Енченко // Физическая культура, спорт - наука и практика. - 2013. - № 2. C. 33-38.

4. Федорова, О.Н. Влияние оздоровительного комплекса «Пилатес и аквааэробика» на составляющие здоровья женщин среднего возраста / О.Н. Федорова // Адаптивная физическая культура. - 2011. - № 4 (48). - C. 26-28.

5. Furman, Y.M. Improvement of aerobic energy supply processes in 37-49 years old women by means of complex aqua-fitness trainings' and methodic of endogenous - hypoxic breathing's application / Y.M. Furman, S.V. Salnikova // Pedagogics, psychology, medical-biological problems of physical training and sport. - 2015. - Vol. 7. - P. 59-69. 
6. Кадыкова, Н.К. Фитнес-тренировки в различные периоды жизни женщин / Н.К. Кадыкова, Л.Е. Фридель, М.А. Шорохова // Сборники конференции НИЦ соџиосфера. - 2016. - № 56. C. $538-543$.

7. Куница, Ю.Б. Особенности проведения занятий по фитнесу с женщинами среднего возраста / Ю.Б. Куница // Наука-2020. - 2016. - № 3 (9). - С. 133-138.

8. Ланская, О.В. Аквааэробика как средство реабилитаџии женщии 30-40 лет с ожирением I-II степени / О.В. Ланская, Л.А. Сазонова, Т.Г. Герасимова // Научный вестник. - 2017. № 2 (12). - C. 79-90.

9. Martinova, N.P. Viznachennia motiviv ta interesiv studentok VNZ do zaniat' z fizichnogo vikhovannia / N.P. Martinova // Naukovo-pedagogichni problemi fizichnoi kul'turio. - 2015. - Vol. 3 (57, 15). P. $218-222$.

10. Martinova, N.P. Novi vidi aerobiki, iak zasib rozvitku rukhovikh iakostej studentok VNZ / N.P. Martinova // Slobozhans'kij naukovo-sportivnij visnik. - 2014. - Vol. 1 (39). - P. 62-65.

11. Martyniuk, O.V. Justification for experimental methods for circuit training aerobics classes first mature age women / O.V. Martyniuk // Pedagogics, psychology, medical-biological problems of physical training and sports. - 2014. - Vol. 11. - P. 30-37.

12. Сафронова, Д.В. Значимость поведенческой мотивации как критерия сегментирования клиентов при разработке программ персонализации фитнес услуг / Д.В. Сафронова, А.Ю. Полякова // Журнал У. Экономика. Управление. Финансы». - 2018. - № 1 (11). - С. 70-76.

13. Оздоровительно-тренировочные эффекты интервальной аэробной тренировки у женщин зрелого возраста / Н.С. Сафронова, Е.В. Иконникова, А.В. Фоменко и др. // Наука, фитнес, реакриачия-2015. - 2015. - № S. - C. 147-152.

14. Тодосюк, С.В. Уровень здоровья и темпы старения у женщин, занимаюшихся фитнесом / С.В. Тодосюк, О.В. Горша // Актуальные проблемы транспортной медицины. - 2014. № 2-2 (36). - C. 80-83.

15. Использование упражнений аэробной направленности в рамках силовой тренировки / А.В. Воронков, И.Н. Никулин, Х.Х. Абуезидов и др. // Научный журнал ДИСКУРС. - 2018. № 11 (25). - C. 19-24.

Перевалина Елена Андреевна, аспирант, Кубанский государственный университет физической культуры, спорта и туризма. 350015, г. Краснодар, ул. Буденного, 161. E-mail: perevalinaelena@yandex.ru, ORCID:0000-0001-8288-9357.

Шестаков Михаил Михайлович, доктор педагогических наук, профессор, кафедра теории и методики футбола и регби, Кубанский государственный университет физической культуры, спорта и туризма. 350015, г. Краснодар, ул. Буденного, 161. E-mail: shmm@mail.ru, ORCID: 0000-0001-6051-4861.

Самуэль Августин Лаггао, доктор философии, кафедра биокинетики и медико-санитарного просвещения, руководитель отдела биокинетики и медицинского образования, Университет Ньялы, Фритаун, Сьерра-Леоне. E-mail: laggao@yandex.ru, ORCID: 0000-0002-0623-0726.

Поступила в редакцию 5 мая 2019 г.

\section{ОБРАЗЕЦ ЦИТИРОВАНИЯ}

Perevalina, E.A. Effect of Different Fitness Programs on the Morphological Parameters of Women Aged 30-40 Years / E.A. Perevalina, M.M. Shestakov, S.A. Laggao // Человек. Спорт. Медицина. - 2019. - Т. 19, № S1. C. $18-23$. DOI: $10.14529 / \mathrm{hsm} 19 \mathrm{~s} 102$

\section{FOR CITATION}

Perevalina E.A., Shestakov M.M., Laggao S.A. Effect of Different Fitness Programs on the Morphological Parameters of Women Aged 30-40 Years. Human. Sport. Medicine, 2019, vol. 19, no. S1, pp. 18-23. DOI: $10.14529 / \mathrm{hsm} 19 \mathrm{~s} 102$ 